\title{
No allelopathic effect of the invader Acacia dealbata on the potential infectivity of arbuscular mycorrhizal fungi from native soils
}

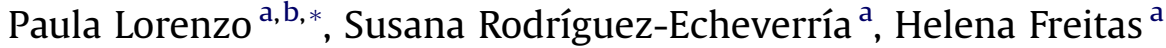 \\ ${ }^{a}$ Centre for Functional Ecology, Department of Life Sciences, University of Coimbra, 3000-455 Coimbra, Portugal \\ ${ }^{\mathrm{b}}$ Departamento de Bioloxía Vexetal e Ciencia do Solo, Universidade de Vigo, E-36310 Vigo, Spain
}

\section{A R T I C L E I N F O}

\section{Article history:}

Received 14 January 2013

Received in revised form

22 March 2013

Accepted 2 June 2013

Available online 21 June 2013

Handling editor: Kristina Lindström

\section{Keywords:}

Allelochemical compounds

Arbuscular mycorrhizal fungi (AMF)

Natural leachates

Plant invasion

Plantago lanceolata

\begin{abstract}
A B S T R A C T
The invasion success of the leguminous tree Acacia dealbata Link has been related to the release of novel chemical compounds that affect both native plant performance and native soil bacterial communities. However, the allelopathic effect of $A$. dealbata on arbuscular mycorrhizal fungi (AMF) has not been explored. We used natural leachates from invasive A. dealbata and native soils to assess the bioactivity of these chemicals on AMF colonization of Plantago lanceolata in native soils. The highly mycorrhizal P. lanceolata was used as a model-test species to estimate the infectivity of AM fungi. Acacia leachates did not affect mycorrhizal colonization in any of the native soils studied. Either the leachates released by A. dealbata do not have an antifungal effect or the analyzed soils contained AMF species resistant to those allelochemicals. Our results appeal for further research to elucidate the role of native AMF in the invasion process of $A$. dealbata.
\end{abstract}

() 2013 Elsevier Masson SAS. All rights reserved.

\section{Introduction}

The "novel weapons hypothesis" postulates that the success of exotic plants might be related to the release of allelochemical compounds that are novel to native species [1], since exotic and native species have not developed mutual tolerance in the course of a joint evolutionary process [2,3]. Although this theory was originally proposed for plant species, exotic plants can also modify microbial communities by releasing novel chemical compounds into the soil $[4,5]$. Some invasive plant species can lead to the disruption of native mycorrhizal fungal communities [6,7]. For example, allelochemicals released by invasive plants reduce AMF abundance, growth and colonization, and spore germination in invaded sites [6,8-11]. Mycorrhizal fungi form symbiosis with $90 \%$ of plant species, which are dependent on this association for growth and survival [12]. Changes in native mycorrhizal communities by invasive exotic species usually have negative effects on native plant species leading to a rapid degradation of the invaded ecosystem $[6-8,13,14]$.

\footnotetext{
* Corresponding author. Centre for Functional Ecology, Department of Life Sciences, University of Coimbra, 3000-455 Coimbra, Portugal. Tel.: +351 239855 244; fax: +351239855211.

E-mail address: paulalorenzo@uvigo.es (P. Lorenzo).
}

Acacia dealbata Link is a leguminous tree native to Australia that has become an aggressive invader around the world [15]. Allelopathy has been invoked to partially explain the invasion success of A. dealbata since naturally-released chemical compounds of this invasive species were shown to interfere with European species and favor its own seeds [16]. Seed germination, seedling growth, net photosynthetic rate, respiration rate and growth of several plant species are all affected by leachates from $A$. dealbata [17-20]. In addition, the genetic structure and diversity of soil microbial communities in native shrublands and grasslands and the functional diversity of the soil bacterial community from native pine forests can also be altered by natural leachates of this Australian species $[5,21]$.

The present study aims to analyze the potential allelopathic effect of this invader on the infectivity of arbuscular mycorrhizal fungi (AMF). Our hypothesis was that $A$. dealbata releases allelochemicals that lead to a decrease of AMF colonization in native soils.

\section{Material and methods}

\subsection{Collection of natural leachates}

The allelopathic effect of $A$. dealbata was assessed by collecting natural leachates that represent natural concentrations of chemical 
Table 1

Locations and characteristics of the native ecosystems where soil collection was done.

\begin{tabular}{|c|c|c|c|}
\hline Ecosystem & Coordinates & Site & Soil type \\
\hline Quercus forest & $40^{\circ} 12^{\prime} 50.34^{\prime \prime} \mathrm{N} 8^{\circ} 23^{\prime} 58.56^{\prime \prime} \mathrm{W}$ & $\begin{array}{l}\text { Coimbra, } \\
\text { Portugal }\end{array}$ & Lithosol \\
\hline $\begin{array}{l}\text { Pinus pinaster } \\
\text { open forest }\end{array}$ & $40^{\circ} 5^{\prime} 39.01^{\prime \prime} \mathrm{N} 8^{\circ} 14^{\prime} 32.99^{\prime \prime} \mathrm{W}$ & $\begin{array}{l}\text { Lousã, } \\
\text { Portugal }\end{array}$ & Lithosol \\
\hline $\begin{array}{l}\text { Shrubland of Erica } \\
\text { and Ulex spp }\end{array}$ & $42^{\circ} 6^{\prime} 3.12^{\prime \prime} \mathrm{N} 8^{\circ} 38^{\prime} 32.73^{\prime \prime} \mathrm{W}$ & Tui, Spain & Umbrisol \\
\hline Grassland & $40^{\circ} 13^{\prime} 7.80^{\prime \prime} 8^{\circ} 22^{\prime} 26.86^{\prime \prime} \mathrm{W}$ & $\begin{array}{l}\text { Coimbra, } \\
\text { Portugal }\end{array}$ & Cambisol \\
\hline
\end{tabular}

compounds, a requirement to be able to interpret allelopathy within an ecological context [13].

Natural leachates collection of $A$. dealbata was conducted in Coimbra, Portugal $\left(40^{\circ} 12^{\prime} 30.50^{\prime \prime} \mathrm{N} 8^{\circ} 24^{\prime} 4.21^{\prime \prime} \mathrm{W}\right)$ during the rainy season in February 2011. Time collection was selected to coincide with the flowering stage of $A$. dealbata, since this is the peak of production and release of allelochemicals for this species $[18,19]$. Detailed description of leachates collection can be found in Lorenzo et al. [5]. Distilled water was used as a control. The pH was 6.25 and 5.70 for acacia leachate and distilled water respectively. The ionic concentration of naturally-collected Acacia leachates is below the toxic threshold for phytotoxicity $[18,19]$.

\subsection{Soil collection}

Soil was collected in the last week of April 2012 from four different non-invaded locations (Table 1 ). Six samples of the top soil layer $\left(0.25 \mathrm{~m}^{2}\right.$ and $10 \mathrm{~cm}$ deep) were randomly collected in each site. Soil samples from the same origin were pooled, stones and roots were manually removed and soil samples were stored in open bags at room temperature. The experiment was done within two weeks after soil collection.

\subsection{Experimental setup}

The experimental design consisted of 4 soil types (Quercus forest, Pinus pine forest, shrubland, grassland) $\times 2$ leachate types (natural leachate from the acacia stand, distilled water). Twenty pots were filled with $100 \mathrm{ml}$ of field soil from each site. Ten seeds of Plantago lanceolata L., a model species in mycorrhizal studies, were sown in each pot and subsequently thinned to obtain one seedling per pot. Pots were placed outdoors at the Botanical garden of University of Coimbra $\left(40^{\circ} 12^{\prime} 22.94^{\prime \prime} \mathrm{N} 8^{\circ} 25^{\prime} 28.66^{\prime \prime} \mathrm{W}\right)$ for nine weeks. Pots were watered with $10 \mathrm{ml}$ of either $A$. dealbata leachates or distilled water as needed. Treatments were replicated 10 times. At the end of the experiment, roots were cleaned, dried at $60{ }^{\circ} \mathrm{C}$ for $48 \mathrm{~h}$ and subsequently used for determining mycorrhizal colonization.

\subsection{Assessment of AMF root colonization}

Dried roots of each seedling were rehydrated in distilled water, chopped into $1 \mathrm{~cm}$ long fragments and stained according to Walker [22]. Mycorrhizal colonization was assessed using a modified grid-line intersection method [23]. For each sample, occurrence of hyphae, vesicles and arbuscules was recorded at least in 100 intersections points. Vesicles were very rare and values of hyphae and vesicles were added up for data analysis.

\subsection{Statistical analysis}

We used a one-way ANOVA for each site to test whether leachate type has an effect on the root colonization of $P$. lanceolata by AMF. Verification of normality and homogeneity of variance were assessed by Kolmogorov-Smirnoff test and Levene test respectively. The level of significance was fixed at $P \leq 0.05$. Statistical analyses were performed using SPSS v.19.0 for Windows.

\section{Results and discussion}

No effect of the $A$. dealbata leachates on the root colonization by arbuscular mycorrhizal fungi (AMF) was detected in any of the studied soils (Fig. 1). The percentage of $P$. lanceolata AMF root infection was around $90 \%$ in all studied soils (Fig. 1). A. dealbata leachates did not affect either the abundance of arbuscules. The mean values of arbuscules colonization in distilled water and $A$. dealbata leachates were respectively $77.31 \pm 1.83$ and $73.14 \pm 0.84$ in the soil from Pinus forest, $84.06 \pm 3.41$ and $83.02 \pm 2.97$ in the soil from Quercus forest, $87.17 \pm 2.13$ and $85.81 \pm 2.20$ in the grassland soil, and $93.06 \pm 1.55$ and $91.01 \pm 1.04$ in the shrubland. These results did not support our hypothesis that naturally-released allelopathic compounds of $A$. dealbata modify the colonization of $P$. lanceolata by native AMF. Our results did not agree with previous works testing the effect of novel chemicals of other aggressive invaders on AMF that found strong negative allelopathic effects e.g. $[6,8]$. Therefore, we show that mycorrhizal degradation is not a universal rule for plant invasion. These results suggest that either the leachates released by $A$. dealbata do not have an antifungal effect or that the analyzed soils contained AMF species resistant to those allelochemicals. Using soils from four different ecosystems ensures that the analyzed AMF communities are different [24], and therefore, resistance of the AMF from the four different soils is more unlikely than a general absence of allelopathic effect on AMF. However, this study did not analyze the
Pinus forest

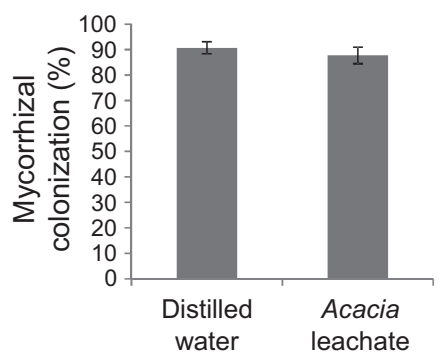

Quercus forest

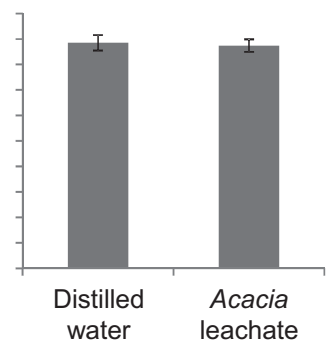

Grassland

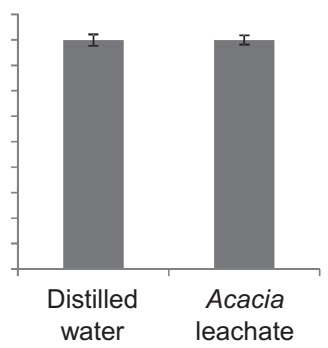

Shrubland

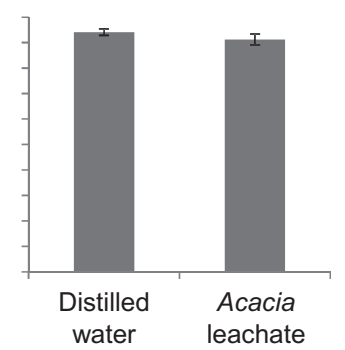

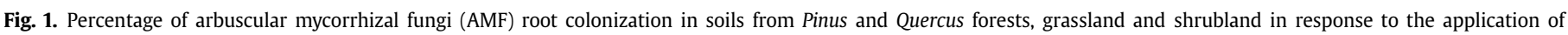
naturally-released allelochemicals of Acacia dealbata. Data are mean $\pm \mathrm{SE}, n=10$. No significant differences were found (One-way ANOVA, $P \geq 0.05$ ). 
composition of the AMF colonizing plant roots and we cannot discard changes in the AMF community structure. On the other hand, allelochemicals can be degraded by microbial activity reducing its toxicity [4,25-27] and this could be an alternative explanation for the obtained results.

In conclusion, allelopathic compounds released in field conditions by the invasive $A$. dealbata do not seem to affect native AMF colonization of $P$. lanceolata. However, these results do not imply that AMF are not involved in the invasion by $A$. dealbata. Recent research has showed that the insensitivity of mycorrhizal fungi to allelochemicals may enhance their allelopathic effect for native plants through the transport of these chemicals through common mycorrhizal networks [25]. On the other hand, non-native plants may benefit of mycorrhizal associations in invaded areas [28]. As an example, the growth and development of the invader Ambrosia artemisiifolia is increased by the presence of AMF [29]. AMF can also alter the outcome of competitive interactions between invasive and native species. Invasive species such as Centaurea maculosa and Ardisia crenata benefit from the presence of AMF when competing with native plants through nutrient sharing via the mycorrhizal network [30,31]. Since A. dealbata can form mycorrhiza in invaded sites (personal observation), it might be taking advantage of the native AMF communities to colonize and invade ecosystems in new geographical areas.

\section{Acknowledgments}

This work was supported by the project MUTUALNET (PTDC/BIA BEC/103507/2008), from the European Union and the Portuguese Foundation for Science and Technology and by post-doctoral research grant from the Spanish Ministerio de Educación (Programa Nacional de Movilidad de Recursos Humanos del Plan Nacional de I-D+i 2008-2011, Ref. EX2010-1169) awarded to Paula Lorenzo.

\section{References}

[1] R.M. Callaway, E.T. Aschehoug Invasive plants versus their new and old neighbors: a mechanism for exotic invasion, Science 290 (2000) 521-523.

[2] M.J. Reigosa, A. Sánchez-Moreiras, L. González, Ecophysiological approaches to allelopathy, Crit. Rev. Plant Sci. 18 (1999) 577-608.

[3] R.M. Callaway, W.M. Ridenour, Novel weapons: invasive success and the evolution of increased competitive ability, Front. Ecol. Environ. 2 (2004) 436-443.

[4] Inderjit, D.A. Wardle, R. Karban, R.M. Callaway, The ecosystem and evolutionary contexts of allelopathy, Trends Ecol. Evol. 26 (2011) 655-662.

[5] P. Lorenzo, C.S. Pereira, S. Rodríguez-Echeverría, Differential impact on soil microbes of allelopathic compounds released by the invasive Acacia dealbata Link, Soil Biol. Biochem. 57 (2013) 156-163.

[6] K.A. Stinson, S.A. Campbell, J.R. Powell, B.E. Wolfe, R.M. Callaway, G.C. Thelen, S.G. Hallet, D. Prati, J.N. Klironomos, Invasive plant suppresses the growth of native tree seedlings by disrupting belowground mutualisms, PLoS Biol. 4 (5) (2006) e140.

[7] R.A. Lankau, Intraspecific variation in allelochemistry determines an invasive species' impact on soil microbial communities, Oecologia 165 (2011) 453-463.
[8] R.M. Callaway, D. Cipollini, K. Barto, G.C. Thelen, S.G. Hallett, D. Prati, K. Stinson, J. Klironomos, Novel weapons: invasive plant suppresses fungal mutualists in America but not in its native Europe, Ecology 89 (2008) 1043-1055.

[9] E.K. Barto, P.M. Antunes, K. Stinson, A.M. Koch, J.N. Klironomos, D. Cipollini, Differences in arbuscular mycorrhizal fungal communities associated with sugar maple seedlings in and outside of invaded garlic mustard forest patches, Biol. Invasions 13 (2011) 2755-2762.

[10] A. Cantor, A. Hale, J. Aaron, M.B. Traw, S. Kalisz, Low allelochemical concentrations detected in garlic mustard-invaded forest soils inhibit fungal growth and AMF spore germination, Biol. Invasions 13 (2011) 3015-3025.

[11] A.N. Hale, S. Kalisz, Perspectives on allelopathic disruption of plant mutualisms: a framework for individual- and population-level fitness consequences, Plant Ecol. 213 (2012) 1991-2006.

[12] S.E. Smith, D.J. Read, Mycorrhizal Symbiosis, Academic Press, San Diego, CA, 2008

[13] D. Cipollini, C.M. Rigsby, E.K. Barto, Microbes as targets and mediators of allelopathy in plants, J. Chem. Ecol. 38 (2012) 714-727.

[14] D.L. Mummey, M.C. Rillig, The invasive plant species Centaurea maculosa alters arbuscular mycorrhizal fungal communities in the field, Plant Soil 288 (2006) 81-90.

[15] D.M. Richardson, M. Rejmánek, Trees and shrubs as invasive alien species - a global review, Divers. Distrib. 17 (2011) 788-809.

[16] P. Lorenzo, L. González, M.J. Reigosa, The genus Acacia as invader: the characteristic case of Acacia dealbata Link in Europe, Ann. For. Sci. 67 (2010) 1011-101-11.

[17] P. Lorenzo, E. Pazos-Malvido, L. González, M.J. Reigosa, Allelopathic interference of invasive Acacia dealbata: physiological effects, Allelopath. J. 22 (2008) 452-462.

[18] P. Lorenzo, E. Pazos-Malvido, M.J. Reigosa, L. González, Differential responses to allelopathic compounds released by the invasive Acacia dealbata Link (Mimosaceae) indicate stimulation of its own seed, Aust. J. Bot. 58 (2010) 546-553.

[19] P. Lorenzo, A. Palomera-Pérez, M.J. Reigosa, L. González, Allelopathic interference of invasive Acacia dealbata Link on the physiological parameters of native understory species, Plant Ecol. 212 (2011) 403-412.

[20] P. Lorenzo, E. Pazos-Malvido, M.J. Reigosa, L. González, New method to check allelopathy of Acacia dealbata under competitive interactions, Allelopath. J. 29 (2012) 271-286.

[21] P. Lorenzo, S. Rodríguez-Echeverría, L. González, H. Freitas, Effect of invasive Acacia dealbata Link on soil microorganisms as determined by PCR-DGGE, Appl. Soil Ecol. 44 (2010) 245-251.

[22] C. Walker, A simple blue staining technique for arbuscular mycorrhizal and other root-inhabiting fungi, Inoculum 56 (2005) 68-69.

[23] T.P. McGonigle, M.H. Miller, D.G. Evans, G.L. Fairchild, J.A. Swan, A new method which gives an objective measure of colonization of roots by vesicular-arbuscular mycorrhizal fungi, New Phytol. 115 (1990) 495-501.

[24] M. Opik, A. Vanatoa, E. Vanatoa, M. Moora, J. Davison, J.M. Kalwij, U. Reier, M. Zobel, The online database MaarjAM reveals global and ecosystemic distribution patterns in arbuscular mycorrhizal fungi (Glomeromycota), New Phytol. 188 (2010) 223-241.

[25] E.K. Barto, J.D. Weidenhamer, D. Cipollini, M.C. Rillig, Fungal superhighways: do common mycorrhizal networks enhance below ground communication? Trends Plant Sci. 17 (2012) 633-637.

[26] R.A. Lankau, Soil microbial communities alter allelopathic competition between Alliaria petiolata and a native species, Biol. Invasions 12 (2010) 2059-2068.

[27] X. Zhu, J. Zhang, K. Ma, Soil biota reduce allelopathic effects of the invasive Eupatorium adenophorum, Plos One 6 (2011) e25393.

[28] K.O. Reinhart, R.M. Callaway, Soil biota and invasive plants, New Phytol. 170 (2006) 445-457.

[29] B. Fumanal, C. Plenchette, B. Chauvel, F. Bretagnolle, Which role can arbuscular mycorrhizal fungi play in the facilitation of Ambrosia artemisiifolia L. invasion in France? Mycorrhiza 17 (2006) 25-35.

[30] M.J. Marler, C.A. Zabinski, R.M. Callaway, Mycorrhizae indirectly enhance competitive effects of an invasive forb on a native bunchgrass, Ecology 80 (1999) 1180-1186.

[31] S.R. Bray, K. Kitajima, D.M. Sylvia, Mycorrhizae differentially alter growth, physiology, and competitive ability of an invasive shrub, Ecol. Appl. 13 (2003) 565-574. 